\title{
Dermatology
}

\section{Alan Lyell}

1917-2007

One of the great old men of dermatology died these days, on 2nd November 2007, two days short of his 90th birthday.

Alan was born to a British Army officer in India, how fitting for a gentleman of Imperial Britain, a year before the great war ended. His father was laid off from the Army and they returned to England where Alan received training at Pembroke College in Cambridge and at St. Thomas's in London where he qualified in 1942 . He joined 11th Durham Light Infantry and was in active service in many a theatre of World War II until he was wounded in Normandy. After the war, he trained in St. Thomas's, then in Addenbrooke's Hospital in Cambridge and was registrar and senior registrar at the Royal Infirmary in Edinburgh to eventually work in Aberdeen and later take over Glasgow Royal Infirmary.

Alan was a man who did not easily compromise in matters he considered essential for his discipline and its outfit. After one such controversy he quit dramatically from his post. As John Thomson wrote in the obituary in the Glasgow Herald on 28 November 2007 (by the way Joseph Plenck's birthday), 'many of his visions came to pass with the amalgamation of the Glasgow dermatology units, henceforth to be called the Alan Lyell Centre for Dermatology'. Alan was present at the ceremony in 2006.

His name will forever be linked in the history of our discipline to toxic epidermal necrolysis, in tandem with Gottfried Ritter von Rittershain in Prague, one century earlier, with the SSS syndrome of today.

He lived up to the very last period in his house at the West coast of Scotland overlooking the Firth of Clyde, with his (originally two) dog(s), Murdoch and Monroe. Both his wife Rachael and Brian, his son, predeceased him. His daughter Bridget was present when he died. He has three grandsons.

\section{KARGER}

Fax +41613061234

E-Mail karger@karger.ch

www.karger.com (c) 2008 S. Karger AG, Basel $1018-8665 / 08 / 2163-0280 \$ 24.50 / 0$

Accessible online at: www.karger.com/drm

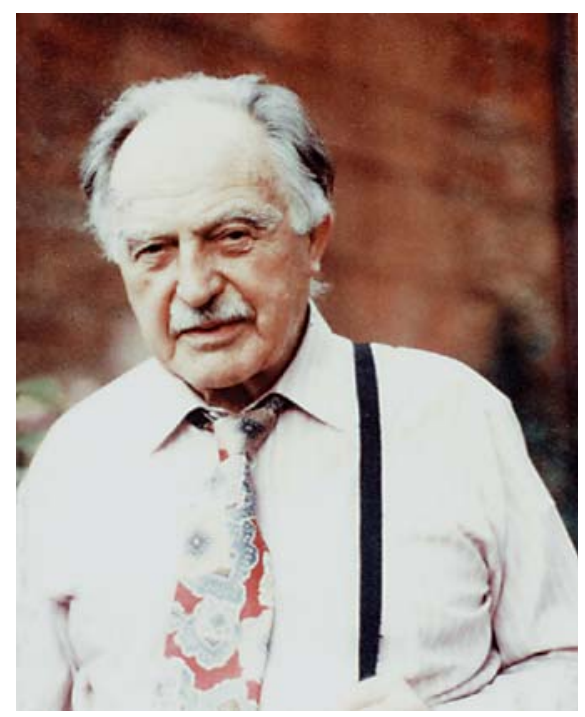

Alan was a true British gentleman of rare distinction, humorous, witty, dry, sarcastic, but warm-hearted all the way. With him, a fascinating story of clinical investigation in dermatology fades into history, reminiscing (Sir) John Arbuthnott, John O'Donnell Alexander, as much as Marion Melish and Alan Glasgow, then in Utah.

Those who knew Alan will never forget him.

May he rest in peace.

Aere perennius.

Karl Holubar, Vienna

Lawrence Charles Parish, Philadelphia

In the name of the American and the European Societies for the History of Dermatology 